\title{
Kitap Değerlendirmesi
}

\section{Kültür Ve İktidar Pierre Bourdieu'nün Sosyolojisi \\ David Swartz}

Çev. E. Gen, İletişim Yayınları, 2011.

\section{Meryem Küçük*}

David Swartz, 20. yüzyılın en önemli sosyologlarından biri olan Bourdieu'nün düşünce yapısı ve fikirleri hakkında önemli bilgiler sunar. Kavramsal ve kuramsal itirazlarını, kuramlarını temellendirdiği dayanak noktalarını, çelişkilerini ve tarihsel bağlamlarını analiz eder. Swartz'a göre, bu eserin amacı; “Anglo-Amerikan yazınında Bourdieu üzerine yapılmış incelemelerde ihmal edilmiş olan noktaları ele almaktır” (s. 16). Buna ilaveten yazar, Bourdieu'nün kavramlarını genel bir kavrayışla sunarak, eleştirel bakışla değerlendirmeyi ve onun eserlerini Fransız entelektüel bağlamda konumlandırmayı hedefler. Nihayetinde, eser sonuç bölümü ile birlikte 12 bölümden oluşmaktadır:

Yazar eserin 1. ve 2. bölümlerinde, Bourdieu'nün "kültür ve iktidar"a yönelik bakışını ve sosyolojisine zemin oluşturan entelektüel bağlam ve araştırma deneyimlerinin üzerinde durur. Kültür, hem insanlar arası etkileşimi hem de tahakkümü sağlamaktadır. Bourdieu, çalışmalarında "tabakalaşmış toplumsal hiyerarşi ve tahakküm sistemlerinin, güçlü bir dirençle karşılaşmaksızın ve toplumun mensuplarınca bilincine varılmaksızın, kuşaklar boyunca nasıl idame edip yeniden üretildiği sorusunun yanıtı aramaktır"(s.18). Bu soruya cevap vermek için kültürel olanakların, süreçlerin, kurumların, birey veya grupların rekabetçi ve tahakküm hiyerarşilerini analiz eder. Kültür ve iktidar iç içe geçmiştir, toplumsal hayatın merkezinde bulunmaktadır. Bourdieu'nün kültür yaklaşımında pratiklerin ve simgesel iktidarın siyasal iktisadını geliştirir; kültürü kendine özgü birikim, mübadele ve kullanım yasaları olan bir sermaye biçimi olarak kavramsallaştır.

\footnotetext{
**Arş. Gör., Sakarya Üniversitesi, Sosyoloji Bölümü, meryemk@sakarya.edu.tr
} 
20. yüzyılın başlarında ortaya çıkan Bourdieu'nün, eserlerinin şekillenmesinde "Ekole Normale Superieure"de aldığı felsefe eğitimi, sosyoloji kuramının üç klasik yazarının etkisi (Marx, Durkeim ve Weber), İkinci Dünya Savaşı sonrası, Fransa'nın genel entelektüel atmosferi özellikle yapısalcılığın etkisi ve Cezayir'deki antropolojik saha çalışması”, belirleyici olmuştur. Swartz’a göre, “Bourdieu’nün sosyolojisi eleştirel ama peygamberce olmayan, kuramsal ama ampirik araştırmaya dayanan, bilimsel ama pozitivist olmayan bir sosyolojidir" (s. 45). Bourdieu, 1970'li yıllarda hem Fransızların kültürel pratik ve hayat tarzına yönelik hem de Cezayir'de topladığı veriler ile iki temel eser ortaya çıkarır; Ayrım/Distiction: A Social Critique of the Judgement of Taste (1979) ve The Logic of Practice (1980). Yine, sömürge dönemi Cezayir üzerine yaptığı çalışma ve The Algerians (1962), Outline of a Theory of Practice (1977), The Logic of Practice (1990) adlı kitaplar1, dil sosyolojisi Language and Symbolic Power (1991) ve kültür sosyolojisi üzerine The Field of Cultural Production (1993) çalışmaları da büyük ilgi görmüştür. Onun eserleri, pozitivizme, ampirizme, yapısalcılığa, varoluşçuluğa, fenomenolojiye, ekonomizme, Marksizm'e, metodolojik bireyciliğe ve büyük kurama karşı yürütülen bir tartışmadır.

Yazar eserin 3. bölüm, Bourdieu'nün “öznelci” ve "nesnelci” bilgi tarzlarına yönelik itirazları ele almakta, bunları "genel bir pratikler kuramı" diye adlandırdığı daha genel bir bilgi çerçevesi içinde bütünleştirme önerisini değerlendirilmektedir, sonra da tözcülük sorununu ele alınıp buna alternatif olarak sunduğu “ilişkisel” çözümleme yöntemi irdelenmiştir. Eserde 4. bölüm ‘den 5. bölüm 'e kadar, Bourdieu'nün sosyolojisini kavramak için belli başlı kavramsal kesişme noktalarını inceler. Bourdieu, maddi ve simgesel boyutları arasındaki ilişkileri yeniden kavramsallaştırmaktadır. Yapısalcı Marksizm'le olan hesaplaşmasının, simgesel çıkar, sermaye olarak iktidar, simgesel şiddet ve simgesel sermaye kuramlarını da içeren bir simgesel iktidar siyasal iktisadi geliştirir. Sermaye biriktirilmiş emektir ve çok farklı biçimler altında somutlaşır. Lakin, genellikle dört sermaye tipinden bahsedilir; iktisadi sermaye (para ve mülk), kültürel sermaye (eğitim de dahil olmak üzere kültürel mallar ve hizmetler), sosyal sermaye (tanışıklıklar ve ilişki ağları), simgesel sermaye (meşruluk). Eserin 5 . ve 6 . bölümlerinde, Bourdieu'nün kültürel eylem kuramı anlatılır ve kuramı inşa eden belli başlı sorular sorulur; "eyleme düzenliğini veren nedir; eylem, kurallara, normlara ya da bilinçli niyetlere itaatin ürünü olmaksızın nasıl düzenli istatistik örüntüler sergiler?” (s. 137). Bu gibi meselelerin cevapları iki kavramla açıklanır: Habitus ve Alan. "Habitus" kavramını işaret etmek üzere "kültürel bilinçdışı”, “alışkanlık oluşturan güç”, “temel, derinlemesine içselleştirmiş büyük örüntüler”, “zihinsel alışkanlık”, “zihinsel ve bedensel algı”, "beğeni ve 
eylem şemaları", “düzenli doğaçlamaları üreticisi ilkesi” gibi ifadeleri kullanır. "Alan” ise habitusun işlev gördüğü toplumsal ortamın yapısını belirler. Alanlar; "malların, hizmetlerin, bilginin ya da statünün öğretildiği, dolaşıma girdiği ve temellük edildiği arenaları ve aktörlerin bu farklı sermaye türlerini biriktirip tekellerine alma mücadelesinde işgal ettikleri, rekabete dayalı konumlarını" ifade eder (s.167).

7. bölümden 9. bölümün sonuna kadar olan kısımdaysa, Bourdieu'nün sosyolojisinde önemli yer tutan (toplumsal sınıf ve iktidar mücadelesi, eğitim, kültür ve eşitsizlik, entelektüeller ve entelektüel alanlar) somut araştırma alanlarına dair kavramsal değerlendirmeler yapılır. Ona göre, kültür ve toplumsal sınıfların karşılıklı ilişkisi bulunmaktadır. Kültürel pratikler, sınıf ayrımına göre şekillenir. Toplum sınıflar, benzer kültürel yatkınlıklara sahip birey ve gruplardan oluşur ve aynı mekândan konumlanır. Birey ve gruplar hiyerarşik yapılanmış toplumsal mekanda konumlarına veya statülerine erişebilmek için bir mücadele verirler. Buna ilaveten, sınıf tahlilinde, sadece meslek ve gelir belirleyici değildir, aynı zamanda hayat tarzını işaret eden unsurlar, beğeniler, eğitim vasıfları, toplumsal cinsiyet ve yaş da önemlidir.

Bir diğer husus ise entelektüellerin sınıfsal konumları itibariyle düşünüldüğünde, hem hakimdirler hem de tahakküm altındadırlar. Belirtilen konuma ulaşabilmek için bir mücadele alanına ihtiyaçları vardır. Buna ilaveten, entelektüel ilgiler aynı zamanda "siyasi" tavırlardır, çünkü faillerin alanlardaki konumlarını korumak ve yükseltmek için izledikleri stratejilerin sonucudurlar. Eserin 10. bölümü ise bilimsel entelektüel ve siyaset ilişkisi irdelenir. Bourdieu'ye göre, entelektüelin temel ve değişmez özelliklerinden biri, “özerlik istenci”dir. Dahası, "Bilim siyasi dünyaya müdahale etmek için kullanılmasını savunur savunmasına ama bu bürokratların, siyasetçilerin veya iş çevrelerinin değil bizzat bilim insanlarının oluşturduğu bilimsel gündem çerçevesinde, bilim adına yapılmalıdır” (s. 359). Son olarak, 11. bölümde Bourdieu'nün düşünümsel sosyoloji pratiği açıklanır. Öncelikli olarak, her sosyolojik olgu incelenirken, o incelemeyi olanaklı kılan toplumsal koşullar ve entelektüeller üzerine eleştirel düşünmeyi gerektirir. Düşünümsel sosyolojide iki temel hedef ortaya çıkar; ilki, “düşünümsellik iyi bir bilim yapmak için şarttır”. İkincisi, “engellenmemiş eleştirel incelemenin ve başkalarıyla iletişimin imkanlarını genişletme yönünde ahlaki bir yükümlülüğe" işaret eder.

Sonuç olarak, Bourdieu'nün sosyolojik incelemelerinin merkezinde, toplumsal eşitsizliği ortaya çıkaran unsurlara karşı neden güçlü bir direniş olmaksızın devam edildiği sorusu yer alır. Bunun cevabı şu şekilde belirtilir; "kültürel kaynakların, pratiklerin ve kurumların eşitsiz toplumsal ilişkileri idame ettirme işlevi görmeleridir”. Bu eser, Bourdieu’nün sosyolojisinin 
detaylı bir şekilde kavranmasını ve anlaşılmasını hedefler. Bunu yaparken de belli başlı kavram ve kuramlar ele alınarak kesişme noktaları belirlenir. Özellikle, Bourdieu'nün "eylem, kültür, iktidar, sınıflaşma ve sosyolojik bilgi hakkında" ayrı ayrı kuramlarına değinilirken, açıklayıcı ve anlaşılır bir dil kullanılmıştır. Diğer yandan, Kültür ve İktidar adlı eser, hem Bourdieu'nün, ileri sürmüş olduğu tez ve tartışma noktalarını anlayabilmemize hem de yaşanan zaman hakkında fikir sahibi olmamıza vesile olur. 